\title{
Becoming original: effects of strategy instruction
}

\author{
Marie-Thérèse van de $\operatorname{Kamp}^{1}$ • Wilfried Admiraal ${ }^{2}$ • \\ Gert Rijlaarsdam ${ }^{1,3,4}$
}

Received: 31 January 2016/Accepted: 9 August 2016/Published online: 26 August 2016

(C) The Author(s) 2016. This article is published with open access at Springerlink.com

\begin{abstract}
Visual arts education focuses on creating original visual art products. A means to improve originality is enhancement of divergent thinking, indicated by fluency, flexibility and originality of ideas. In regular arts lessons, divergent thinking is mostly promoted through brainstorming. In a previous study, we found positive effects of an explicit instruction of metacognition on fluency and flexibility in terms of the generation of ideas, but not on the originality of ideas. Therefore, we redesigned the instruction with a focus on building up knowledge about creative generation strategies by adding more complex types of association, and adding generation through combination and abstraction. In the present study, we examined the effects of this intervention by comparing it with regular brainstorming instruction. In a pretest-posttest control group design, secondary school students in the comparison condition received the brainstorm lesson and students in the experimental condition received the newly developed instruction lesson. To validate the effects, we replicated this study with a second cohort. The results showed that in both cohorts the strategy instruction of $50 \mathrm{~min}$ had positive effects on students' fluency, flexibility and originality. This study implies that instructional support in building up knowledge about creative generation strategies may improve students' creative processes in visual arts education.
\end{abstract}

Keywords Creativity · Divergent thinking · Strategy instruction · Visual arts education

Marie-Thérèse van de Kamp

M.T.A.vandeKamp@uva.nl

1 Research Institute of Child Development and Education, University of Amsterdam, Nieuwe Achtergracht 127, 1018 WS Amsterdam, The Netherlands

2 Leiden University, Leiden, The Netherlands

3 University of Antwerp, Antwerp, Belgium

4 Umea University, Umeå, Sweden 


\section{Introduction}

In visual arts education, divergent thinking is used by students to generate original concepts for designing - domain-specific — visual art works (Schlegel et al. 2015). To produce original ideas, it is useful to generate many (i.e., fluency), different kinds of (i.e., flexibility) ideas, because this increases the possibility of original ideas to be generated (Mednick 1962). To measure divergent thinking skills, fluency, flexibility and originality scores from ideation exercises are often used (Runco 2010). In regular visual arts lessons in secondary schools, generation of original ideas is usually promoted through students performing individual brainstorming exercises (Hetland et al. 2007). Through these brainstorming exercises, students develop a repertoire of generation of ideas and images for an arts product. While brainstorming, students interact with peers and the teacher about the generation of ideas and they construct knowledge about generation of ideas. However, this approach of regular brainstorming exercises may limit the speed and quality of learning, because students will need many different kinds of experiences with brainstorming before they have built a rich knowledge base to enhance their divergent thinking skills. We expect students may develop enhanced divergent thinking skills through explicit instruction of metacognition, because then students may learn to understand why, how and when to use which specific divergent thinking activities and strategies (Askell-Williams et al. 2012; Dignath and Büttner 2008).

To study the effects of explicit instruction about divergent and original idea generation on students' divergent thinking skills, we performed an earlier study in visual arts education with Grade-11 students aged 16-17 (van de Kamp et al. 2015). We found positive effects on students' fluency and flexibility of ideas, but not on students' originality. In hindsight, the intervention mainly focused on generation through association, whereas the key in generating original ideas lies in the generation of remote ideas and in generation through combination and abstraction. Therefore, we redesigned the intervention and addressed in detail, through explicit instruction, knowledge about various strategies of divergent thinking aimed at generation through remoteness, i.e., generation of remote ideas from a stimulus (Benedek et al. 2012; Gilhooly et al. 2007) and through abstractness, i.e., generation through association, combination and abstraction (Hunter et al. 2008; Soderberg et al. 2014). In this way, we wanted to focus more on knowledge about various activities and strategies in divergent thinking. Furthermore we also improved the instructional design of the intervention lesson to enhance students' metacognitive knowledge and skills to regulate-monitor and controlthese thinking processes aimed at generating original ideas. In a quasi-experiment with a pretest post-test control group design, we examined the effects of this renewed intervention on students' fluency, flexibility and originality in divergent thinking tasks by comparing this intervention lesson with a comparison condition, receiving a regular lesson focusing on generation through brainstorming activities and teacher feedback on ideas generated. In order to validate the findings we replicated this study with a second cohort of students.

\section{Theoretical framework}

\section{Two dimensions in divergent thinking: remoteness and abstractness}

Divergent thinking in visual arts is a means to generate original ideas and an original concept to visualize (Bresson 2004). Enhancing students' skills in divergent thinking is 
therefore one of the main objectives in visual arts education (Seidel et al. 2009). Different models have been constructed to analyze and/or stimulate generation, like SCAMPER focusing on general brainstorming techniques (Eberle 2008) or the model of inventive ideation focusing on generation mechanisms (Ross 2006). However, in order to teach divergent thinking activities, we needed specific generation activities in association, combination and abstraction. Therefore, we built a model of twelve divergent thinking activities, along two dimensions-remoteness and abstractness-referred to in Table 1.

Remoteness, is the metaphorical distance from the stimulus (Acar and Runco 2014; Benedek et al. 2012; Gilhooly et al. 2007). To illustrate: in association, we can distinguish at least four types of activities varying in remoteness (Benedek et al. 2012). From (1) free association, associative retrieval from memory takes place, which will in first instance lead to the retrieval of experienced or common ideas. Then, via (2) flexible association, chains of associations are generated, and by switching to associations in different categories more remote ideas can arise. Next, via (3) dissociation, remote associations are developed by

Table 1 Matrix of creative generation activities running from no-remoteness/concreteness (A1) to remoteness/abstractness (C4)

\begin{tabular}{|c|c|c|c|c|c|}
\hline & $\begin{array}{l}\text { C: ABSTRACTION } \\
\text { Increasing complexity in } \\
\text { abstraction: } \\
\text { Apparently remote and } \\
\text { incompatible concepts, } \\
\text { functions or contexts are } \\
\text { analyzed, deconstructed, } \\
\text { restructured and ultimately } \\
\text { transformed on a } \\
\text { structural level through } \\
\text { defocused and focused } \\
\text { attention. }\end{array}$ & $\begin{array}{l}\text { C1: CONSTRUCT } \\
\text { CONCEPTUALLY } \\
\text { Analyzing remote } \\
\text { categories and contexts } \\
\text { on a deep structural level } \\
\text { and constructing novel } \\
\text { concepts through } \\
\text { complex and systematic } \\
\text { combinations. }\end{array}$ & $\begin{array}{l}\text { C2: DECONSTRUCT } \\
\text { Deconstructing concepts, } \\
\text { functions and contexts } \\
\text { on a deep structural level } \\
\text { can be used to analyze } \\
\text { specific structures of } \\
\text { various and apparently } \\
\text { incompatible concepts, } \\
\text { functions or contexts for } \\
\text { restructuring, through } \\
\text { focusing on possible } \\
\text { novel use of these } \\
\text { structures in remote } \\
\text { contexts (disassembly } \\
\text { use). }\end{array}$ & $\begin{array}{l}\text { C3: RESTRUCTURE } \\
\text { Mapping the complex } \\
\text { structure of one concept, } \\
\text { function or context to } \\
\text { restructure another } \\
\text { remote concept, function } \\
\text { or structure in a non- } \\
\text { obvious way } \\
\text { (dissociation). } \\
\text { Problem analysis \& } \\
\text { problem definition: } \\
\text { 1: break-frame/conceptual } \\
\text { change. } \\
\text { 2: relating existing } \\
\text { structures to remote, non- } \\
\text { obvious structures. } \\
\text { 3: combining knowledge } \\
\text { of existing structures for } \\
\text { the creation of new } \\
\text { structures through } \\
\text { analogical thinking. }\end{array}$ & $\begin{array}{l}\text { C4: TRANSFORM } \\
\text { Blending two apparently } \\
\text { incompatible structures } \\
\text { (far transfer) into a } \\
\text { radically new concept, } \\
\text { function or category } \\
\text { through bisociation. This } \\
\text { requires } \\
\text { 1) abstraction: a } \\
\text { systematic comparison of } \\
\text { two concepts on a } \\
\text { structural level (types of } \\
\text { objects or categories). } \\
\text { 2) complex combination: } \\
\text { mapping similarities on a } \\
\text { structural level that can } \\
\text { be used to create a novel } \\
\text { structure (analogical or } \\
\text { metaphorical thinking). } \\
\text { 3) the blending of } \\
\text { structures into a novel } \\
\text { structure; a structure is } \\
\text { radically transformed. }\end{array}$ \\
\hline & $\begin{array}{l}\text { B: COMBINATION } \\
\text { Increasing complexity in } \\
\text { combination: } \\
\text { Combining different } \\
\text { features and functions for } \\
\text { broad uses through } \\
\text { imagination and/or through } \\
\text { semantic combinations. }\end{array}$ & $\begin{array}{l}\text { B1: ADJUST } \\
\text { Adding or changing one } \\
\text { of the features or } \\
\text { properties of a specific } \\
\text { object or function } \\
\text { (features like colour, } \\
\text { shape, size, texture) } \\
\text { through association. }\end{array}$ & $\begin{array}{l}\text { B2: MERGE } \\
\text { Flexibly combining all } \\
\text { features or properties of } \\
\text { two or more objects, } \\
\text { subjects or functions. }\end{array}$ & $\begin{array}{l}\text { B3: RECOMBINE } \\
\text { 1) Splitting the object or } \\
\text { function into parts or } \\
\text { functions. } \\
\text { 2) Combining remote } \\
\text { properties and functional } \\
\text { parts for non-obvious, } \\
\text { novel purposes or } \\
\text { functions. }\end{array}$ & $\begin{array}{l}\text { B4: RECONNECT } \\
\text { Using functions in remote, } \\
\text { non-obvious contexts or } \\
\text { for novel, broad use } \\
\text { purposes. (shoe as } \\
\text { 'weapon'). }\end{array}$ \\
\hline 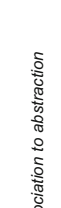 & $\begin{array}{l}\text { A: ASSOCIATION } \\
\text { Increasing complexity in } \\
\text { association: } \\
\text { By combining remote } \\
\text { concepts and generation } \\
\text { of non-obvious or } \\
\text { surprising ideas through } \\
\text { retrieval from long-term } \\
\text { memory and/or through } \\
\text { analogical thinking. }\end{array}$ & $\begin{array}{l}\text { A1: ASSOCIATE } \\
\text { FREELY } \\
\text { Free generation of as } \\
\text { many associations as } \\
\text { possible from a stimulus. }\end{array}$ & $\begin{array}{l}\text { A2: ASSOCIATE } \\
\text { FLEXIBLY } \\
\text { Generation of as many } \\
\text { diverse associations as } \\
\text { possible (chains of } \\
\text { associations). }\end{array}$ & $\begin{array}{l}\text { A3: DISSOCIATE } \\
\text { Generation of unrelated } \\
\text { concepts from a stimulus, } \\
\text { that is generation of as } \\
\text { many remote associations } \\
\text { as possible. }\end{array}$ & $\begin{array}{l}\text { A4: BISOCIATE } \\
\text { Generation of associative } \\
\text { combinations of two } \\
\text { (bisociation) or more } \\
\text { remote concepts. }\end{array}$ \\
\hline 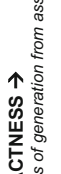 & $\begin{array}{c}\text { GENERATION } \\
\text { OF } \\
\text { ORIGINAL IDEAS }\end{array}$ & $\begin{array}{l}\text { 1: INCREMENTAL } \\
\text { THINKING } \\
\text { To retrieve knowledge } \\
\text { from memory and step- } \\
\text { by-step thinking }\end{array}$ & $\begin{array}{l}\text { 2: FLEXIBLE THINKING } \\
\text { To switch flexibly } \\
\text { between different } \\
\text { categories }\end{array}$ & $\begin{array}{l}\text { 3: REMOTE } \\
\text { THINKING } \\
\text { To think from an entirely } \\
\text { different perspective and } \\
\text { to make mental leaps }\end{array}$ & $\begin{array}{l}\text { 4: SYNTHESIZING } \\
\text { THINKING } \\
\text { Far analogical thinking, } \\
\text { envisioning and mental } \\
\text { blending }\end{array}$ \\
\hline 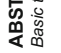 & \multicolumn{5}{|c|}{$\begin{array}{l}\text { REMOTENESS - METAPHORICAL DISTANCE } \rightarrow \\
\text { Types of thinking to generate ideas from more closely related ideas to more remote ideas (from a stimulus). }\end{array}$} \\
\hline
\end{tabular}


taking a mental leap from a stimulus, leading to (4) associative combination, when two or more remote associations are retrieved in combination (Benedek et al. 2012).

Abstractness, runs from no abstraction - the production of mere associative strings- to transformation. On this dimension, we distinguished three classes of divergent thinking, characterized by the key cognitive activity involved: association, combination and abstraction (Hunter et al. 2008; Soderberg et al. 2014). Association is the generation of strings of ideas through memory retrieval (Hunter et al. 2008). Combination is the analysis and (de)composition of ideas, objects or functions (Gilhooly et al. 2007; Jaarsveld and van Leeuwen 2005). Abstraction is structuring, deconstructing, reconstructing and transforming (Welling 2007; Zahner et al. 2010).

If we observe idea generation processes that aim at creating original ideas (through divergent thinking, i.e., through fluency, flexibility and originality), we may expect various combinations of these twelve activities, in various patterns. But when originality is the driving force in such a process, we assume remoteness and abstractness as vectors, that is, we assume movement along two axes: from less to more remote and/or from less to more abstract. In the next section, we will elaborate on this model. In this way, arrangements of creative generation activities can be deliberately used as a strategy to generate more original ideas.

\section{Remoteness in association}

We distinguish four types of associative thinking activities: from incremental thinking in free association, to association that involves mental leaps and mental blends such as associative combination (or bisociation), in which at least two remote associations are blended (Benedek et al. 2012) (see Table 1, A1-A4).

Free association is spontaneous knowledge retrieval from long-term memory, as a response to a certain stimulus. In a think-aloud study with participants performing an alternative uses test, Gilhooly et al. (2007) demonstrated that divergent thinking starts with free association: knowledge is retrieved from episodic memory. Since strongly connected episodes are recalled first, free association is a relatively effortless and automatic process (Kokinov et al. 2007). The first strings of generated ideas are often common: these are the ideas that have been experienced earlier, and they mostly refer to dominant uses (Collins and Loftus 1975). Therefore, to generate uncommon ideas, one should continue, to arrive at more remote ideas (Mednick 1962). Free association, when originality is the aim, thus requires the cognitive skill of association as well as the affective skill of persistence (Nijstad et al. 2010). See cell A1 in Table 1.

Flexible association concerns switching between associative chains of ideas (Benedek et al. 2012). Switching between ideational categories increases the possibility that original ideas emerge. Ideas then, are not only retrieved from episodic memory via association, but also from semantic memory, for example through metaphorical thinking. Switching is enhanced by reduced levels of latent inhibition (Peterson et al. 2002) and by the cognitive skill to switch flexibly between different ideational categories (Nijstad et al. 2010). See cell A2 in Table 1.

Dissociation is characterized by mental leaps made forward towards remote ideas. Leaping forward is a short-cut route towards more remote ideas when associating (Benedek et al. 2012; Ross 2006). Mental leaps can originate from automatic processes or deliberate approaches. Automatic processes involve priming of remote associations through defocused attention and reduced latent inhibition (Kiefer et al. 1998; Peterson et al. 2002). A deliberate process is built on experience-with these remote association processes aimed at 
finding more original ideas-which means one can deliberately opt for a strategy that focuses on automatic processes or one can opt for 'taking a cultivated chance' (Perkins 1994, p. 131). To go far beyond the usual, such an approach must involve the inhibition of dominant uses. Dissociation can lead to original ideas in a faster way than via incremental thinking through association, but it may also lead to nowhere. It needs risk-taking as well as a non-evaluative attitude and an open-mind, because one has to accept that even inappropriate ideas can be generated that might not be useful. See cell A3 in Table 1.

Associative combination or bisociation Bisociation occurs when two or more remote and apparently incompatible ideas are blended (Benedek et al. 2012). It originates from analogical thinking (i.e., using information from one from one domain (source) and using it another domain (target) and from categorizing concepts in broader and unusual ways. This demands reduced levels of inhibition to make mental leaps as well as an open-mind to accept bizarre thoughts that might result in original ideas (Benedek et al. 2012). See cell A4 in Table 1.

\section{Remoteness in combination}

In combination, cognitive activities such as analyzing and (de)composing are added to the basic generating activities involved in association. In this process of combination, mapping is an analytic activity that precedes all combinatorial generation. It consists of analysis and ordering of correspondences of either features, properties or grouping (Holyoak and Thagard 1989). Mapping requires - real or envisioned-perceptual analysis, intuitive or deliberate. Intuitive perceptual mapping processes are based on implicit memory integration according to aesthetic principles (familiarity, proto-typicality, peak shifts). Deliberate perceptual mapping processes are based on applying explicit classification of types, functions and contexts (Leder et al. 2004). Following these mapping activities, combination can take place via adjusting and merging (Sawyer 2012). Adjusting and merging result in ideation that remains rather close to the stimulus, although merging is a more complex activity than adjusting.

Adjusting uses information from comparison or metaphorical thinking and changes one feature only, for example changing the colour or the texture of an object (Smith and Osherson 1984). See cell B1 in Table 1.

Merging means that all features of two objects or functions are combined into a hybrid form, through addition or integration (Gibbert et al. 2012; Hampton 1987). See cell B2 in Table 1.

Recombination More remote combinations can be created by decomposing and mapping specific features, parts or functions. Subsequently, separate features, parts or functions can be recombined to construct new objects or to create novel functions (Gilhooly et al. 2007; Michalko 1991). See cell B3 in Table 1.

Reconnection By including contextual aspects in generation, more remote or unusual combinations can be constructed. Broad use activities, for example, take an existing function (such as 'transport') but reconnect it to a remote context (such as 'weapons', or 'aesthetics'). This process may lead to more original outcomes (Gilhooly et al. 2007; Jaarsveld and van Leeuwen 2005). See cell B4 in Table 1.

\section{Remoteness in abstraction}

Abstraction creates schematic knowledge, i.e., new concept structures, through structuring, deconstructing and reconstructing. Basic operations are pattern discovery and class creation (i.e., creating a new category class). 
Construct conceptually Association creates specific, concrete examples. Once these concrete examples are represented at a more abstract level, it becomes easier to cross modalities and domains (Cohen and Murphy 1984; Hampton 1996; Ward et al. 2004). In this way, complex concepts can be constructed. One example here is Piet Mondrian's 'Pier and Ocean' (Composition, nr. 10, 1915). This composition exclusively consists of horizontal and vertical black lines representing universal structures, such as the powers of nature, depicted in basic shapes on a two-dimensional canvas. Mondrian analyzed the complexity of a three-dimensional world in space and time: the transparency and threedimensionality of the water, the sparkling reflections of sunlight moving on the surface, the continuous movements of waves in different directions, the slow tidal movements in time and space, the view of a curved horizon above the ocean, and the contrast with the immovable, rectangular wooden pier. He thus constructed a concept in which all of these aspects are combined and yet abstracted. Mondrian simultaneously visualized both the complexity and the essence of the powers of nature, space and time. For Mondrian, this work also marked a first stage towards non-representational painting (See Fig. 1). See cell $\mathrm{C} 1$ in Table 1.

Deconstruction Deconstruction consists of critical analysis of concepts, functions and contexts into separate structures and re-composing these elements in a novel way to form contexts that, at first sight, appear to be remote contexts. This process is also defined as the first phase of 'disassembly use' (Gilhooly et al. 2007). One example is 'Phonebloks', a novel modular concept to deconstruct a smartphone into separate elements and functions, like toy Lego bricks. This concept presents a more customer-friendly way of composing and repairing mobile phones and therefore also a more sustainable way of producing them. See cell C2 in Table 1.

Restructuring In the restructuring process, the complex structure of one concept, function or context is used to restructure another remote concept, function or context in a non-obvious way (Davidson and Sternberg 2003; Gentner and Markman 1997). One example is the 'NeoNurture incubator', in which two remote 'worlds' were used: car parts and the principles of car mechanics were used for the design of a low-maintenance infant incubator for the developing world. See cell C3 in Table 1.

Transformation Transformation is the most complex and remote creative activity, because 'a creator has to think in a new, tweaked way about a solution, a problem, a structure or a domain' (Boden 2004, pp. 3-5). Due to this radical new way of thinking

Fig. 1 Construction of complex concepts. Piet Mondrian. Composition no 10. Pier and Ocean. 1915. Collection KröllerMüller Museum, Otterlo, The Netherlands

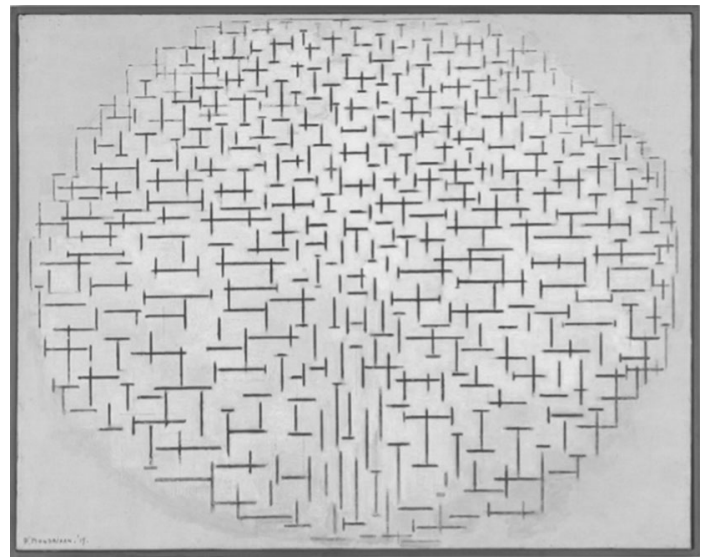


about the problem or the domain, entirely new and non-obvious concepts can be created, 'concepts which could not have been thought of before' (Boden 2004, pp. 3-5). Representing a concept, function or context in an abstract way and/or in a different domain promotes the generation of more remote ideas. The process of abstracting takes place as follows: a mental model is created that is based on deep understanding and/or analogies, as illustrated by Mondrian in his Pier and Ocean. Mondrian later transformed this representational but abstracted painting into non-representational or purely abstract painting, similar to the abstract laws of nature in science. In other words, abstraction can lead to transformations through the mental blending of remote analogies. Abstraction can overcome fixedness and lead to freer generation, because memories of past experiences and concrete situations are less present in the more schematic knowledge (Zahner et al. 2010). See cell C4 in Table 1.

\section{A strategy instruction on divergent thinking}

In the intervention under study, we used explicit instruction focusing on metacognitive strategy knowledge to promote students' divergent thinking skills. This knowledge involved deep understanding of the twelve specific generation activities and the two dimensions of abstractness and remoteness to be used as strategies for generating original ideas for visual arts products. Studies on regulation of learning processes reveal that a good performance requires strategy knowledge about the selection of thinking strategies to be used in different contexts; metacognitive knowledge and metacognitive skills (AskellWilliams et al. 2012; Dignath and Büttner 2008; Ku and Ho 2010; Nelson and Narens 1990). In the intervention, we related strategy knowledge and metacognitive knowledge to the activities to be used for divergent thinking in visual arts education.

Metacognitive knowledge Metacognitive knowledge in creative processes involves declarative and conditional knowledge about creativity and divergent thinking and knowledge of tasks, strategies, and self (Flavell 1979). This means students should possess metacognition about divergent thinking tasks, divergent thinking strategies and selfknowledge to decide which strategy to use when and how; to assess the accuracy of their knowledge and choices and to reflect on their improvements in learning to think divergently. This knowledge is required for the regulation-monitoring and control—of task performance and learning processes. Nelson and Narens (1990) proposed a model of metamemory with two levels and a flow of information between these levels. At the objectlevel run executive processes, as task performances and learning processes. At the metalevel runs a dynamic representation of the object-level. It controls and regulates executive processes. Between these levels, two types of information flow: monitoring and control.

Monitoring, is the flow of information from the object-level to the meta-level which may change or confirm the actual state of the meta-level, i.e., the representation of the taskperformance or learning process. The monitoring activity is guided by how the learner assesses the demands and outcomes of a task performance, this can lead to changes in the meta-level.

Control, is the flow of information from the meta-level to the object-level. In control processes, metacognitive knowledge such as task-relevant knowledge about the use of strategies, flows from the meta-level and provides information for the object-level. This information may change the performance of the task concerned. The flow of information between meta-level and object-level is a cyclic process, in which regulation of executive processes is enhanced. 
Metacognitive skills Metacognitive skills are the procedural component of metacognition, skills that are related to monitoring and control of learning - in this case, monitoring and control of learning how to enhance creativity.

Strategy knowledge about divergent thinking Knowledge of complex strategic and executive processes, as divergent thinking, is needed for metacognitive regulation for two reasons. First, it is needed for the construction of a mental model of the performance; secondly, it is needed for the accuracy of control of a strategy (Serra and Metcalfe 2009). Before students are able to control or to improve their divergent thinking processes, they must first build up knowledge about the concepts of divergent thinking and originality (the why, the when and the how) and about specific divergent thinking activities and strategies (Barak 2013; Ranellucci et al. 2013) They also need to learn to monitor, i.e., to observe, analyze and evaluate, divergent thinking (learning) processes to build up conditional and contextual knowledge. Control over the use of divergent thinking that is guided metacognitively, can lead to more effective strategy-use (i.e., divergent thinking skills).

Brainstorming-activities in regular visual arts lessons mainly focus on generating specific ideas, within a specific visual arts task. Usually, there is no explicit instruction of metacognitive knowledge about divergent thinking or metacognitive strategies that can be used in divergent thinking processes. But if students' repertoire of divergent thinking activities and their strategic knowledge is limited, it will hinder students to arrive at more original ideas or to develop more effective (regulation) strategies for divergent thinking. Therefore an instruction should not only focus on enhancement of students metacognitive knowledge, but also on enhancement of students' metacognitive skills for regulation, which might subsequently lead towards enhanced divergent thinking (Table 2).

Focus of this study Enhancement of divergent thinking, requires knowledge on why, when and how to generate original ideas. We expected students need explicit instruction of metacognition to enhance their divergent thinking skills, because then students may learn to understand why, how and when to use which specific divergent thinking activities and strategies (Askell-Williams et al. 2012; Dignath and Büttner 2008). Positive effects were found of an explicit instruction on metacognition on grade 11 (age 16,17) students' skills in fluency and flexibility but not on originality (van de Kamp et al. 2015). Therefore, we have redesigned the intervention, by focusing on students developing knowledge about twelve specific divergent thinking activities and knowledge about strategies in divergent thinking focusing on two dimensions, of remoteness and abstractness to generate more original ideas (See Table 1), and by focusing on the instructional design and ways to enhance students' metacognitive knowledge and skills for regulation processes related to divergent thinking strategies (See Table 3), to improve students' divergent thinking in three respects-fluency, flexibility and originality. We compared this intervention with a regular brainstorm lesson in visual arts, which is commonly used for the generation original ideas for concepts to be visualized in an arts product. Our main research question was:

Does a metacognitive strategy instruction enhance students' divergent thinking, i.e., their fluency, flexibility and originality, more than a regular brainstorm-lesson in visual arts education? 


\section{Method}

We used a pre-test post-test control group design for two cohorts, with Cohort 2 as the replication to validate the effects found in Cohort 1 . This validation supports the generalization of the findings for students and teachers. In Cohort 1, 102 students were grouped in four classes, which we randomly assigned to either the experimental condition or the comparison condition. We label the control condition as the comparison condition, because both conditions received an intervention lesson (see 'Interventions' below). In Cohort 2, 117 students were grouped in five classes, which we randomly assigned to the experimental condition (three classes) or to the comparison condition (two classes). In both conditions and in both cohorts, students worked on an identical photography project entitled 'Timegrasping' that was aimed at original visualizations of students' concepts of time (Stocker 2012).

\section{Participants}

Participants were two cohorts of students from one single school for secondary education in the Netherlands. Cohort 1 included 102 Grade-11 students (age 16-17; $40 \%$ females) and Cohort 2 included 117 Grade-11 students (age 16-17; $52 \%$ females). We opted for Grade-11 students at pre-university level because we wanted to include the same age/level group that had participated in our previous study and because we knew that these students would understand and be interested in the complex content of the intervention lesson. The students from both cohorts attended compulsory classes in cultural and arts education of $1 \mathrm{~h}$ per week. Students, their parents and the three art teachers involved provided their consent to participate in the study.

All lessons were taught through team-teaching in two dyads. In each dyad, the first author participated, who gave the major part of the introductory lesson and the intervention lesson (for all groups in both conditions) with, in that lesson, the other teacher assisting before the lesson, and observing students during the lesson. The other lessons consisted predominantly of guided art production and art reception lessons where both teachers participated equally and in equal roles as co-teachers. During the post-test held in Cohort 1 , eleven students were absent because of extracurricular activities or illness; in Cohort 2, three students were absent due to extracurricular activities. The intervention lessons of both conditions and in both cohorts were taught by one and the same instructor, who participated in all other lessons as co-teacher.

\section{Design}

The intervention lesson for the experimental condition and regular brainstorm lesson for the comparison condition for both cohorts were part of a visual arts project. This project was part of the regular curriculum and took 14 weeks with one lesson of 50 min per week. Students were credited for their work with a grade for their final art production and art reception assignments as well as written descriptions and reflections concerning their art process. Either in week 4 or in week 5 of the project, students in both conditions received an intervention lesson. Students from the experimental condition received one 50-min intervention lesson by the first author with assistance from the second teacher, with explicit instruction on metacognitive knowledge about creativity, on divergent thinking activities and on strategies about originality in visual art-photography-products as well as on 
metacognitive skills for regulation activities. Students in the comparison condition received instead a regular brainstorm lesson of $50 \mathrm{~min}$, also delivered by the first author with assistance from the second teacher, with an instruction that showed examples of different types of brainstorm processes in art, an assignment focusing on envisioning and instruction focusing on analyzing knowledge and skills required for brainstorming-processes in visual arts. In this way, students of the comparison condition were stimulated to develop an accurate task representation. The experimental and comparison condition only differed in this one intervention lesson of 50 min of the project of 14 lessons.

The lessons between pre-test and intervention were exactly the same for all students involved, for both conditions and both cohorts. Between the pre-test and the intervention, all students received one lesson with an explanation of the theme of 'Time-grasping' and all assignments and criteria; one technical lesson about and exercises with photography and one lesson with individual art reception assignments. The lessons between intervention and post-test were also exactly the same for all students involved. Between the intervention and the post-test, all students from both conditions received one lesson with individual art reception and reflection assignments and one lesson with an individual assignment on photography. Between Cohort 1 and 2 there was only one difference before the pre-test based on pragmatic reasons. Cohort 1 immediately started with the alternative uses pre-test while Cohort 2 started with lesson 1,-a photography assignment was added for all students involved-and then the pre-test (alternative uses test) was performed in lesson 2. (See Table 2).

\section{Interventions}

We based the instructional design for the experimental condition on various sources (See Table 3). First, the specific order of lesson phases was based on studies about the

Table 2 Design: lesson weeks and assignments for Cohort 1 and 2

\begin{tabular}{|c|c|c|}
\hline $\begin{array}{l}\text { Cohort } 1 \\
\text { lesson week }\end{array}$ & $\begin{array}{l}\text { Cohort } 2 \\
\text { lesson week }\end{array}$ & $\begin{array}{l}\text { Assignments } \\
\text { for Cohort } 1 \text { and } 2\end{array}$ \\
\hline- & 1 & Independent art production (only Cohort 2) \\
\hline 1 & 2 & Performing alternative uses test 1 (fixed time: $5 \mathrm{~min}$ ) \\
\hline 2 & 3 & Introduction on the theme \\
\hline 3 & 4 & Technical lesson about photography \& art production \\
\hline 4 & 5 & $\begin{array}{l}\text { Intervention lesson for experimental and comparison } \\
\text { condition }\end{array}$ \\
\hline 5 & 6 & Art reception assignment \\
\hline 6 & 7 & Guided art production \\
\hline 7 & 8 & Independent art production \\
\hline 8 & 9 & Performing alternative uses test 2 (fixed time: $5 \mathrm{~min}$ ) \\
\hline 9 & 10 & Independent art production \\
\hline 10 & 11 & Independent art production \\
\hline 11 & 12 & Peer-feedback on art reception assignment \\
\hline 12 & 13 & Peer-feedback on art production \\
\hline 13 & 14 & Independent art production \\
\hline 14 & - & Independent art production \\
\hline
\end{tabular}


structuring of instructional-learning episodes (Elshout-Mohr et al. 1999; Merrill 2001, 2002). Secondly, specific learning goals for visual analysis and for exercises were focused on real world examples and exercises in brainstorming in visual arts. This was based on an effect study about creativity training (Scott et al. 2004). Thirdly, the way learning activities and metacognitive strategies were incorporated in the lesson, was based on studies about strategy knowledge of higher order thinking processes and on enhancing students' metacognitive regulation through metacognitive strategy instruction (Houtveen and van de Grift 2007; Schraw 1998). Fourthly, the instructional activities were set up as explicit instruction of metacognitive strategies, based on studies demonstrating the importance of explicit instruction of metacognition, teacher modeling and observational learning (Dignath and Büttner 2008; Groenendijk et al. 2013; van de Kamp et al. 2015). Fifthly, ways to enhance metacognitive regulation processes of monitoring and control were based on the Nelson and Narens' model of metacognition (1990). Table 1.2 of Schraw and Gutierrez (2015, p. 11) with a hybrid strategy instruction model for metacognitive strategy instruction was used to check the way metacognitive strategy instruction was applied in our intervention.

The intervention lesson of the comparison condition was a more regular brainstorm lesson, we used a study about effects of creativity training about the importance of realworld exercises in brainstorming (Scott et al. 2004) and a study on studio art (Hetland et al. 2007) to check the content and exercises of the regular brainstorm lesson. In the comparison condition, the rather abstract theme of 'Time' and the way in which this theme is visualized in art and science was explored through analyzing examples from art. Furthermore, the assignments on art production and art reception were explained and students performed brainstorm activities, like an exercise using an alternative uses prompt to generate many, different kinds of original ideas for photography series. Students' received feedback on their brainstorm ideas (See Table 4).

\section{Experimental condition: Explanation of learning activities and instructional activities}

In short, the metacognitive strategy instruction contained five lesson-phases. We first focused on students' conceptions and beliefs about their creativity skills and about metacognitive knowledge about creativity (orientation on metacognitive knowledge). Furthermore, students received explicit instruction about knowledge and skills used for regulation of creative processes and divergent thinking (metacognitive strategy instruction). Through whole-class discussion, new knowledge about divergent thinking strategies was illustrated with visual examples. To integrate this new knowledge, students exercised with various divergent thinking strategies (divergent thinking strategy instruction). Finally, they reflected on the relevance of their newly acquired knowledge (evaluation). We shall explain the learning activities in these five phases in greater detail below; the numbers in the text refer to Table 3.

Orientation on metacognitive knowledge $(8 \mathrm{~min})$ Students' prior knowledge about creativity was activated (1) by raising students' self-awareness through self-evaluation of their own creativity. Students also received explicit instruction on metacognitive knowledge about creative processes. To motivate and engage students, we asked them to think about solving real-world visual design problems, which we then linked (2) to learning about how to regulate these types of creative problem-solving processes.

Metacognitive strategy instruction $(15 \mathrm{~min})$ The concept of creativity and of divergent thinking and how this is related to creative processes was exemplified (3) with visual examples as a foundation for understanding divergent thinking strategies. In this way, new 
Table 3 Intervention lesson for experimental condition-explicit metacognitive strategy instruction about divergent thinking

\begin{tabular}{|c|c|c|c|}
\hline $\begin{array}{l}\text { Lesson phases/ } \\
\text { learning goals }\end{array}$ & $\begin{array}{l}\text { Learning activities and } \\
\text { metacognitive strategies }\end{array}$ & $\begin{array}{l}\text { Instructional activities that lead to } \\
\text { learning activity and metacognition }\end{array}$ & $\begin{array}{l}\text { Rationale for enhanced monitoring } \\
\text { and control processes }\end{array}$ \\
\hline $\begin{array}{l}\text { 1: Activating prior } \\
\text { knowledge. }\end{array}$ & $\begin{array}{l}\text { Reflecting, self-evaluating - } \\
\text { Reflecting on students' conceptions } \\
\text { about creativity.Self-evaluating } \\
\text { (mis)understandings about } \\
\text { creativity. }\end{array}$ & $\begin{array}{l}\text { Questioning: What do you know about } \\
\text { creativity? Asking students about their } \\
\text { concepts of creativity. }\end{array}$ & $\begin{array}{l}\text { Monitoring - Enhancing learning and } \\
\text { monitoring through clarifying } \\
\text { knowledge and misunderstandings } \\
\text { about creativity in general and about } \\
\text { students' own creativity. }\end{array}$ \\
\hline $\begin{array}{l}\text { 2: Linking motivational } \\
\text { components to self- } \\
\text { regulated learning; } \\
\text { engaging students in } \\
\text { solving real-world } \\
\text { problems. }\end{array}$ & $\begin{array}{l}\text { Focusing, relating, } \\
\text { understanding - Focusing on main } \\
\text { ideas, objectives and overall } \\
\text { meaning of creativity in society and } \\
\text { for students' own learning. }\end{array}$ & $\begin{array}{l}\text { Whole-class discussion about } \\
\text { examples of innovative art and design; } \\
\text { interviewing students about their } \\
\text { concepts of creativity and experiences } \\
\text { with creativity. }\end{array}$ & $\begin{array}{l}\text { Monitoring - Enhancing learning and } \\
\text { monitoring through tying knowledge of } \\
\text { the concept to the value of } \\
\text { creativity;transforming this new } \\
\text { knowledge into something personally } \\
\text { meaningful. }\end{array}$ \\
\hline $\begin{array}{l}\text { 3: Exemplifying } \\
\text { divergent thinking as a } \\
\text { strategy and when and } \\
\text { how it should be used; } \\
\text { formative assessment of } \\
\text { understanding. }\end{array}$ & $\begin{array}{l}\text { Observing, analyzing, } \\
\text { understanding, integrating, } \\
\text { checking and reflecting - } \\
\text { Understanding through observing } \\
\text { and analyzing examples. } \\
\text { Summarizing and synthesizing new } \\
\text { knowledge through reflective } \\
\text { questions. }\end{array}$ & $\begin{array}{l}\text { Direct instruction and whole-class } \\
\text { discussion about declarative, } \\
\text { procedural, conditional and contextual } \\
\text { knowledge of creative processes and } \\
\text { about divergent thinking as a strategy. } \\
\text { Relating new knowledge to existing } \\
\text { knowledge through reflective } \\
\text { questions and checking } \\
\text { understanding. }\end{array}$ & $\begin{array}{l}\text { Monitoring - Enhancing learning and } \\
\text { monitoring by transforming new and } \\
\text { rather abstract and complex } \\
\text { knowledge into visible and concrete } \\
\text { models. }\end{array}$ \\
\hline $\begin{array}{l}\text { 4: Applying knowledge. } \\
\text { Collaborative use and } \\
\text { student modeling of the } \\
\text { strategy in action. }\end{array}$ & $\begin{array}{l}\text { Applying, modeling, analyzing - } \\
\text { Elaborating knowledge by applying. } \\
\text { Exercising and creating own } \\
\text { examples/experiences of the } \\
\text { strategy in action. }\end{array}$ & $\begin{array}{l}\text { Exercising with an alternative uses test } \\
\text { - for a tablet computer. Student } \\
\text { modeling of the strategy in action. }\end{array}$ & $\begin{array}{l}\text { Monitoring and control - Creating } \\
\text { meta-level model. Monitoring ongoing } \\
\text { learning. Constructing a model of } \\
\text { divergent thinking strategy to be } \\
\text { learned. }\end{array}$ \\
\hline $\begin{array}{l}\text { 5: Evaluating the } \\
\text { originality of ideas } \\
\text { generated. }\end{array}$ & $\begin{array}{l}\text { Evaluating, relating, analyzing, } \\
\text { focusing - Evaluating the } \\
\text { originality of ideas generated. } \\
\text { Focusing on the relevance of the } \\
\text { main concepts and strategies. }\end{array}$ & $\begin{array}{l}\text { Through whole-class discussion, } \\
\text { students exchange ideas about the } \\
\text { originality of the answers given to } \\
\text { construct new concepts on divergent } \\
\text { thinking; students compare and } \\
\text { combine old and new concepts on } \\
\text { creative generation strategies. }\end{array}$ & $\begin{array}{l}\text { Monitoring and control - Selecting } \\
\text { relevant control strategies. Interactive } \\
\text { discussion and expert guidance } \\
\text { provide examples of skilled monitoring, } \\
\text { strategy evaluation and } \\
\text { implementation of control processes. }\end{array}$ \\
\hline $\begin{array}{l}\text { 6. Explicit instruction } \\
\text { and description of } \\
\text { divergent thinking as a } \\
\text { strategy. }\end{array}$ & $\begin{array}{l}\text { Observing, structuring, } \\
\text { reflecting, integrating - Focusing } \\
\text { on and highlighting key ideas; } \\
\text { integrating concepts and themes } \\
\text { and meta-level understanding } \\
\text { through discussion. }\end{array}$ & $\begin{array}{l}\text { Direct instruction; teacher modeling } \\
\text { with whole-class discussion about } \\
\text { knowledge on thinking strategies used } \\
\text { in creative processes. Developing self- } \\
\text { knowledge through reflection, about } \\
\text { growth thinking and effects of 'feeling } \\
\text { to improve'. }\end{array}$ & $\begin{array}{l}\text { Control - Highlighting/accentuating by } \\
\text { the teacher can assist students to } \\
\text { focus on main ideas and construct } \\
\text { meta-level models of divergent } \\
\text { thinking as a strategy and of the } \\
\text { benefits of creative self-efficacy. }\end{array}$ \\
\hline $\begin{array}{l}\text { 7. Explicit instruction } \\
\text { and description of } 12 \\
\text { divergent thinking } \\
\text { strategies (See Table } \\
\text { 1), illustrating these with } \\
\text { visual examples and } \\
\text { teacher modeling of the } \\
\text { strategy. }\end{array}$ & $\begin{array}{l}\text { Observing, analyzing, relating, } \\
\text { reflecting, integrating - Focusing } \\
\text { on specific divergent thinking } \\
\text { strategies; Integrating concepts } \\
\text { and strategies. } \\
\text { Promoting meta-level } \\
\text { understanding by teacher modeling } \\
\text { of strategies and dialogue. }\end{array}$ & $\begin{array}{l}\text { Direct instruction; teacher modeling } \\
\text { and whole-class discussion about four } \\
\text { different divergent thinking strategies } \\
\text { in a) association b) combination and c) } \\
\text { abstraction. Relating these to } \\
\text { examples of visual art and design and } \\
\text { the concept of originality } \\
\text { (decontextualisation / } \\
\text { recontextualisation). }\end{array}$ & $\begin{array}{l}\text { Monitoring and control - Creating } \\
\text { meta-level model. Highlighting/ } \\
\text { accentuating can assist students to } \\
\text { focus on main ideas and constructing } \\
\text { meta-level model of new strategies. } \\
\text { Interactive discussion and expert } \\
\text { guidance provide examples of skilled } \\
\text { monitoring, strategy selection and } \\
\text { implementation of control processes. }\end{array}$ \\
\hline $\begin{array}{l}\text { 8. Independent use of } \\
\text { the strategies. }\end{array}$ & $\begin{array}{l}\text { Applying, generating, reflecting - } \\
\text { Promoting meta-level } \\
\text { understanding through application. }\end{array}$ & $\begin{array}{l}\text { Students practise with an alternative } \\
\text { uses test for divergent thinking. } \\
\text { Students are asked to go beyond } \\
\text { clichés and to produce original } \\
\text { solutions for the uses of.. }\end{array}$ & $\begin{array}{l}\text { Monitoring and control - Focusing on } \\
\text { main ideas and constructing meta- } \\
\text { level model. Integrated meta-level } \\
\text { model facilitates selection of self- } \\
\text { regulation strategies. }\end{array}$ \\
\hline $\begin{array}{l}\text { 9. Integration of new } \\
\text { knowledge into the } \\
\text { learner's world. }\end{array}$ & $\begin{array}{l}\text { Analyzing, evaluating, } \\
\text { integrating - Relating information } \\
\text { by evaluating, analyzing and } \\
\text { discussing examples to help } \\
\text { organize information. }\end{array}$ & $\begin{array}{l}\text { Students receive feedback from their } \\
\text { peers about the originality of their } \\
\text { ideas and discusse the effectiveness } \\
\text { of strategies used. }\end{array}$ & $\begin{array}{l}\text { Control - Interactive discussion } \\
\text { provides examples of monitoring, } \\
\text { strategy selection and implementation } \\
\text { of control processes. }\end{array}$ \\
\hline $\begin{array}{l}\text { 10. Constructing higher } \\
\text { order knowledge and } \\
\text { integrating this } \\
\text { knowledge. }\end{array}$ & $\begin{array}{l}\text { Relating, self-evaluating, } \\
\text { structuring - Construction of a } \\
\text { meta-level mental model through } \\
\text { feedback, teacher modeling and } \\
\text { peer discussion. }\end{array}$ & $\begin{array}{l}\text { Feedback and whole-class discussion } \\
\text { and reflection on different divergent } \\
\text { thinking strategies with examples } \\
\text { related to the alternative uses test that } \\
\text { students performed. The concept of } \\
\text { originality in relation to divergent } \\
\text { thinking strategies was re-introduced. }\end{array}$ & $\begin{array}{l}\text { Control - A mental model serves as a } \\
\text { basis to monitor and self-regulate } \\
\text { ongoing control processes. }\end{array}$ \\
\hline $\begin{array}{l}\text { 11. Creating knowledge } \\
\text { through generating and } \\
\text { predicting. Evaluating } \\
\text { and integrating } \\
\text { knowledge through } \\
\text { reflection. }\end{array}$ & $\begin{array}{l}\text { Predicting, generating, creating, } \\
\text { evaluating, reflecting, integrating } \\
\text { - Evaluating learning by generating } \\
\text { new ideas related to the } \\
\text { photography assignment. }\end{array}$ & $\begin{array}{l}\text { Individually: predicting how divergent } \\
\text { thinking strategies can result in original } \\
\text { photographs. To stimulate self- } \\
\text { evaluation of students' understanding. } \\
\text { Students are asked to relate and } \\
\text { evaluate two different examples of } \\
\text { originality in photography to the } \\
\text { knowledge and concepts about } \\
\text { divergent thinking strategies. }\end{array}$ & $\begin{array}{l}\text { Monitoring - Reflecting on mental } \\
\text { model at meta-level; checking } \\
\text { understanding, relating conclusions } \\
\text { and performance } \\
\text { outcomes to the model. }\end{array}$ \\
\hline
\end{tabular}


knowledge about creativity was related (a) to the meta-level and (b) to students' own creative experiences. We checked students' understanding via reflective questions. To deepen understanding, new knowledge about creativity was then applied (4) through collaborative use and through student modeling of divergent thinking as a strategy to generate ideas in action. Ideas generated were then evaluated by whole class discussion (5) and the individual pool of ideas generated by each student was analyzed by each student, focusing on when most original ideas had occurred and also on if, why and how persistence and flexibility had resulted in more original ideas. Here, students were expected to obtain a deeper understanding of the nature of divergent thinking processes. Then, through direct instruction and teacher modeling of divergent thinking as a strategy to generate ideas was explained as were the metacognitive skills needed for executing this strategy (6) as well as the importance of divergent thinking for problem finding. Through a reflective discussion about the mindset required (growth mindset and feeling to improve), students were stimulated to construct a mental model of creative self-efficacy.

Divergent thinking strategy instruction (18 min) Twelve different divergent thinking strategies (see Table 1) were explained (7) and exemplified through direct instruction and teacher modeling. Divergent thinking strategies were each illustrated with visual examples and demonstrated via teacher modeling, again with explicitly demonstrating when and how the strategies could be used. Students were stimulated to reflect on this new knowledge through whole-class discussion. Then, new knowledge was applied (8) in an alternative uses test for divergent thinking. Students practised with generating many, different kinds of original ideas and were asked to be aware of a limited amount of time and simultaneously be aware of the process of executing divergent thinking strategies using the new knowledge they obtained, like postponing their evaluation. Then students were stimulated to integrate (9) new knowledge: in dyads, students analyzed and evaluated their most original ideas, reflected on how and when these ideas were generated (through which strategy), and they considered the effectiveness of the strategies they used. Higher order knowledge was constructed (10) through feedback and whole-class discussion, explanation and the demonstration of specific divergent thinking strategies and examples of ideas that could have been generated in the exercise used. In this way, students evaluated the originality of their own ideas generated, which stimulated the integration of this knowledge with students' own experience in using divergent thinking strategies.

Evaluation (9 min) Finally, students evaluated and integrated new knowledge about creativity and divergent thinking through reflective questions. Students had to predict (11) — while using divergent thinking strategies-how 'time' could be visualized in photography in original ways. These reflective questions stimulated students to self-evaluate the knowledge obtained from this lesson and to reflect on their performance in this art assignment. The intervention is presented in Table 3.

\section{Comparison condition: Explanation of learning activities and instructional activities}

In short, students in the comparison condition received a regular brainstorm lesson in the same week (5/6) with an instruction given by the first author. The intervention lesson of the comparison condition contained three phases. First, students' prior knowledge about the theme was activated and students were stimulated to explore, envision and reflect about the concept of 'Time-grasping' (Orientation). Secondly, the instruction focused on refining students task-representation (Instruction and whole-class discussion). Thirdly, to arrive at an original series of photographs for their final assignments, students evaluated their photographs from previous lessons and continued with brainstorming activities and they 
Table 4 Regular brainstorm lesson for comparison condition

\begin{tabular}{|c|c|c|c|}
\hline $\begin{array}{l}\text { Lesson phases/ } \\
\text { learning goals }\end{array}$ & Learning activities & $\begin{array}{l}\text { Instructional activities that lead to } \\
\text { learning activity }\end{array}$ & $\begin{array}{l}\text { Rationale for implicit monitoring } \\
\text { and control processes }\end{array}$ \\
\hline $\begin{array}{l}\text { 1: Activating prior } \\
\text { knowledge. }\end{array}$ & $\begin{array}{l}\text { Exploring, envisioning, reflecting } \\
\text { - Exploring, envisioning and } \\
\text { reflecting on the theme of 'Grasping } \\
\text { Time' and students' questions } \\
\text { about the theme of 'Grasping Time' } \\
\text { and the assignments. }\end{array}$ & $\begin{array}{l}\text { Questioning: Can you envision what } \\
\text { you will be thinking the day after } \\
\text { tomorrow, about what you were } \\
\text { thinking and feeling at this very } \\
\text { moment? In this way we are in fact } \\
\text { 'mentally travelling through time'. } \\
\text { The teacher showes examples of time } \\
\text { as a concept, the visualizing of time in } \\
\text { photography, through movement or } \\
\text { light and shadow. }\end{array}$ & $\begin{array}{l}\text { Monitoring - Implicitly stimulating } \\
\text { monitoring through clarifying } \\
\text { knowledge and misunderstandings } \\
\text { about the theme of 'Grasping Time' } \\
\text { and about the assignments. }\end{array}$ \\
\hline $\begin{array}{l}\text { 2: Linking assignments } \\
\text { of previous lessons to } \\
\text { the theme of 'Grasping } \\
\text { Time' and to all } \\
\text { assignments and the } \\
\text { time-schedule. }\end{array}$ & $\begin{array}{l}\text { Focusing, understanding - } \\
\text { Focusing on main ideas, objectives } \\
\text { and overall meaning of time as a } \\
\text { theme in art and science. }\end{array}$ & $\begin{array}{l}\text { Questioning: Do you have questions } \\
\text { so far about the theme of 'Grasping } \\
\text { Time' and about the assignments you } \\
\text { will have to do? } \\
\text { Students respond with questions } \\
\text { about both the theme and the } \\
\text { assignments. Further explaning the } \\
\text { theme. Whole-class discussion about } \\
\text { examples of the theme of 'time' in } \\
\text { visual arts and science. }\end{array}$ & $\begin{array}{l}\text { Monitoring - Implicitly stimulating } \\
\text { monitoring through tying knowledge of } \\
\text { the concept of 'time' to the technique } \\
\text { of photography and relating this to the } \\
\text { assignment students had to perform: } \\
\text { to make their own original } \\
\text { visualization of 'time' in a photography } \\
\text { series of three photographs. }\end{array}$ \\
\hline $\begin{array}{l}\text { 3: Exemplifying how } \\
\text { photography and visual } \\
\text { arts could be used for } \\
\text { transforming the - } \\
\text { abstract notion - of time } \\
\text { into an image. }\end{array}$ & $\begin{array}{l}\text { Observing, analyzing, } \\
\text { understanding - Understanding } \\
\text { through observing and visually } \\
\text { analyzing examples. }\end{array}$ & $\begin{array}{l}\text { Direct instruction about declarative } \\
\text { and procedural knowledge of time and } \\
\text { various examples of the visualization } \\
\text { of time in visual arts and photography. } \\
\text { Original examples of the visualization } \\
\text { of the abstract notion of time and the } \\
\text { way it was used in for example } \\
\text { 'sequences' of time or in 'evidence' of } \\
\text { time (dust, traces - of light, marks, } \\
\text { etc.). }\end{array}$ & $\begin{array}{l}\text { Monitoring - Implicitly stimulating } \\
\text { monitoring by transforming new and } \\
\text { rather abstract knowledge of the } \\
\text { concept of 'time' into visible and } \\
\text { concrete examples from visual arts. }\end{array}$ \\
\hline $\begin{array}{l}4: \text { Evaluating the } \\
\text { originality of students' } \\
\text { own photography series. }\end{array}$ & $\begin{array}{l}\text { Analyzing, evaluating - Analyzing } \\
\text { and evaluating the originality of the } \\
\text { photography series that students } \\
\text { had already made. }\end{array}$ & $\begin{array}{l}\text { Students analyze their own } \\
\text { photography series, analyze their } \\
\text { concepts of time and the way they } \\
\text { visualize this. They evaluate the } \\
\text { originality of their concepts and their } \\
\text { photographs, and think of improved } \\
\text { ideas for tjeir photography series. }\end{array}$ & $\begin{array}{l}\text { Control and monitoring - Implicitly } \\
\text { stimulating control and monitoring } \\
\text { processes, by stimulating } \\
\text { implementation of control processes. }\end{array}$ \\
\hline $\begin{array}{l}\text { 5: Applying knowledge } \\
\text { about photography and } \\
\text { many ways to make } \\
\text { photographs on the } \\
\text { concept of 'time' } \\
\text { (generation of new } \\
\text { ideas). }\end{array}$ & $\begin{array}{l}\text { Applying, generating- Exercising } \\
\text { and creating own examples of } \\
\text { photography and original ways to } \\
\text { visualize the concept of time. }\end{array}$ & $\begin{array}{l}\text { Exercising with 'brainstorming } \\
\text { activities' related to students' own } \\
\text { photography assignment. Students } \\
\text { start brainstorming about their own } \\
\text { individual photography series, they } \\
\text { are going to realize in the next weeks. } \\
\text { They exercise with an alternative uses } \\
\text { brainstorm-test and are asked to } \\
\text { generate as many, different kinds of } \\
\text { original ideas for photographs to be } \\
\text { made. Then they are stimulated to } \\
\text { generate even more new ideas for } \\
\text { concepts and photography- } \\
\text { techniques. }\end{array}$ & $\begin{array}{l}\text { Control - Stimulating self-regulation of } \\
\text { ongoing control processes about } \\
\text { making an original photography } \\
\text { series. }\end{array}$ \\
\hline $\begin{array}{l}\text { 6. Integration of new } \\
\text { knowledge into the } \\
\text { learner's world. }\end{array}$ & $\begin{array}{l}\text { Evaluating, analyzing, } \\
\text { understanding, integrating - } \\
\text { Evaluating, analyzing and } \\
\text { discussing examples to help } \\
\text { understanding information of this } \\
\text { lesson about 'time' and visualization } \\
\text { of this abstract theme into concrete } \\
\text { and original photographic works. }\end{array}$ & $\begin{array}{l}\text { Students receive feedback from their } \\
\text { peers about the originality of their } \\
\text { ideas and discusse the effectiveness } \\
\text { of concepts and photography } \\
\text { techniques used. }\end{array}$ & $\begin{array}{l}\text { Control - Interactive discussion } \\
\text { provides examples of monitoring, } \\
\text { evaluation criteria and stimulates } \\
\text { (implicitly) implementation of control } \\
\text { processes. }\end{array}$ \\
\hline
\end{tabular}

performed an 'alternative uses' exercise. Students had been asked to bring the photographs they had made in the previous lessons to use for brainstorming activities for their final assignment. They received feedback on their ideas (Evaluation, exercise and feedback). The instruction in the comparison condition was brief, because teachers mainly focused on individual feedback about students' brainstorming process and when, how and why to 
improve this process, thus stimulating critical reflection and self-evaluation. No explicit metacognitive strategy instruction on divergent thinking took place in the brainstormlesson of the comparison condition. We shall explain the learning activities in the lesson phases in greater detail below; the numbers in the text refer to Table 4 (See Table 4).

Orientation (14 min) Students were shown several illustrations of the theme 'Time' drawn from art and science. Thus, many different original ideas about the visualization of time were shown to model different types of brainstorm processes. Students also performed an assignment focusing on 'envisioning' and why, how and when to improve originality of ideas through envisioning. In this way, students' prior knowledge about the subject of 'Time-grasping' was activated and students were stimulated to explore, envision and reflect (1) about the theme.

Instruction about the theme and whole-class discussion focusing on task-representation (18 min) Students received an instruction about the purpose of the assignments and about the learning goals of the lessons. They were also given the opportunity to ask questions about the assignment and about the learning goals, in this way students were stimulated to focus on their understanding (2) of the assignments. The content of the theme was then illustrated with more specific examples drawn from visual art and design that reflected 'Time', and through analyzing knowledge and skills involved in brainstorming in visual arts, students were stimulated to develop an accurate task representation. In this way we stimulated students to observe, analyze and understand (3) how artists transformed the abstract concept of 'time' into concrete visual images in order to feed students' repertoire of possibilities.

Evaluation, exercise with brainstorming and feedback (18 min) Students analyzed and evaluated (4) their first series of photographs in relation to the theme of 'time-grasping' and then continued to brainstorm individually, about a new photography series to be made. Next, they were asked to design as many different kinds of original ideas as possible for their own photography series on 'Time-grasping' to stimulate students to persist in generation of ideas. This was an 'alternative uses' exercise focusing on generation of new ideas for photography series (5). Students discussed their brainstorm ideas with peers (peer assessment and peer feedback) as well as with the two arts teachers present in the class in this way they were stimulated to integrate (6) new knowledge about the theme and about evaluating and reflecting their specific and new ideas for photographs, from this lesson.

\section{Fidelity measures}

To align the intervention lessons of both the experimental and the comparison condition provided by the first author, a colleague observed the lesson and the students' responses. After the intervention lessons of both conditions, a discussion followed between the observer and the first author to check whether the intervention lesson had been performed as planned and whether students seemed to have understood the content of the lesson. The observers confirmed that each intervention lesson was indeed performed according to the lesson plan. Through their observations of the students and through questions they asked to several students at the end of the lesson, they also concluded that students had been able to understand the content of the lesson. Additionally, in all lessons for both the experimental and the comparison condition, one teacher observed while the latter was teaching. 


\section{Measures}

We applied computerized alternative uses test for pre-tests (Cohort 1: week 1; Cohort 2: week 2) and post-tests (Cohort 1: week 8; Cohort 2: week 9). Students were asked to generate as many different types of original ideas that they could think of (Runco and Okuda 1991) related to a space (Test A) and energy in a space (Test B). As a pre-test for Cohort 1 an alternative uses test (Test A) was administered with computers in which students had to list in $5 \mathrm{~min}$, as many different types of original possibilities as they could for the use of an immense space (of which a photograph was shown, See Fig. 2). For the post-test for Cohort 1, we administered an alternative uses test (Test B) in which students had to list in $5 \mathrm{~min}$ as many different types of original possibilities as they could for the use of energy in an immense space (of which another photograph was shown). These tests were related in a real-world domain-specific task that students received with the project 'Time-grasping' and that concerned the visualization of spacetime in relation to a specific industrial heritage location. These alternative uses tests were similar but not identical. To avoid dependency on a certain fixed sequence of the tests, we varied the order of pre-test and post-test in the two cohorts. For Cohort 2, we administered Test B as pre-test and Test A as post-test. We also switched the photographs. Figure 2 lists the details.

We analyzed students' divergent thinking skills based on the concept of divergent thinking as ways of thinking in many different directions (flexibility) and thus ways of generating many different ideas (fluency) that may lead to many original, unusual or infrequent ideas (Runco 2010). This is why we used fluency, flexibility and originality scores from pre- and post-tests for both cohorts as indicators of divergent thinking.

Fluency was indicated by the number of all corrected responses per student by removing all non-interpretable responses (incomplete words, less than $1 \%$ of the total of all responses) and combining of all similar words while disregarding obvious spelling mistakes, typing errors and articles.

Flexibility was indicated by the number of different categories of the responses for each student. From the data, we generated a total of 17 categories for using 'the immense space' and for 'using energy in the immense space'. The category of flexibility was initially derived from using the 'invention categories' by Finke (1990). We then added categories, related to both of the type of alternative uses assignments (Test A-uses for space-and B-uses for energy in a space) used. First, we listed all answers generated; through induction the categories based on Finke were then elaborated, first by the researchers, then with second rater. Then we performed Test $\mathrm{A}$ and we took a sample of about 50 ideas generated from this test Two raters independently categorized these ideas, according to the first list of categories the research team constructed through induction. The coding was discussed, the categories used were further refined, and rules and exceptions were defined. This procedure was repeated with the new categories and with the rules and exceptions list, but this time we took another sample-from test B-and coded ideas generated. This coding again was discussed and categories were then established and rules and exceptions were also refined. We then had a list of categories as well as a procedure of coding. These categories were (in alphabetical order): (1) activities dealing with care-taking for groups of people like refugees, elderly, children; (2) activities dealing with storage; (3) activities referring to immaterial places/spaces (heaven); (4) activities with/for flora and fauna; (5) activities with (aspects of) this specific space (using aspects of the space/place); (6) eating and drinking living; (7) entertaining; (8) exposing (art, fashion, cars etc.); (9) individual 


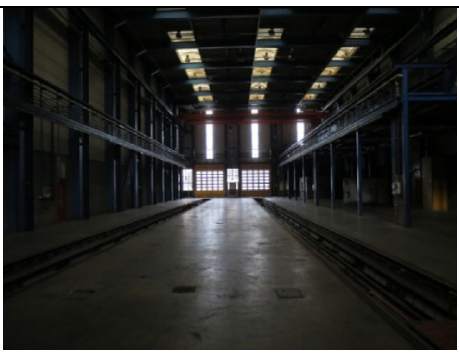

TEST A: Depicted you see an IMMENSE EMPTY SPACE. List as many different types of original ideas you can think of, and what you could do with or in this IMMENSE EMPTY SPACE. Think how you could use this IMMENSE EMPTY SPACE in uncommon ways. A common way might be: you could walk through it. You are supposed to list as many different types of original ideas as possible for using this IMMENSE EMPTY SPACE. You have 5 minutes for this task.

\section{Cohort 1 (pre-test) examples of original answers}

- Fill it with one billion ballpoint pens

- Caress the walls

Make a tv documentary of a space in which trains used to be repaired Create chaos by putting lots of constructions across the space

Use it for parachute jumping

Neglect the space entirely but in such a way that people can still visit it - Use it as a rhinoceros-breeding farm

- Organize night-walking events in it

- Use it as a place to spend your most boring holiday ever

Cohort 1 (pre-test) examples of non-original answers

- Use it as a parking place for automobiles/bikes

Use it as a school

- Build a shopping mall in it

- Use it as a storage space

Build a factory

Make a restaurant in it

- Make an indoor swimming-pool in it

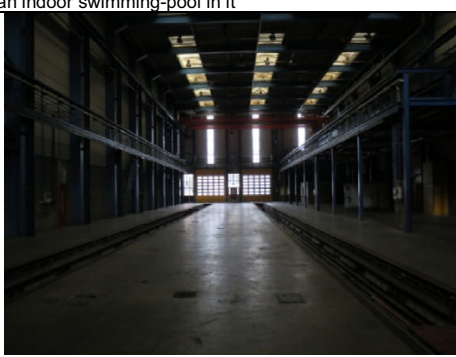

TEST B: Depicted you see an immense empty space. List as many different types of original ideas you can think of, and what you could do or change with energy in this immense empty space. Think how you could use ENERGY in this immense empty space in uncommon ways. A common way might be: you could turn on the lights, you could move trains or walk in it. You are supposed to list as many different types of original ideas as possible for using ENERGY in this immense empty space. You have 5 minutes for this task.

\section{Cohort 2 (pre-test) examples of original answers}

- Have lots of automatic baby buggies riding through the space

- Have people run around in a hamster wheel

Create a lot of extra light by using a lot of mirrors

Hang a merry-go-round on the ceiling

Use it as a giant pizza oven

- Create a trampoline from spun sugar

- Create a tornado with fans and smoke

- Place waterbottles filled with water and bleach that will accentuate the light

- Fill the enitre space with fireflies

Cohort 2 (pre-test) examples of non-original answers

- Build a fitness studio in it

- Repaint it

Light it with many lights

Use it for a party

Use it for a music performance

Use it as a filmset

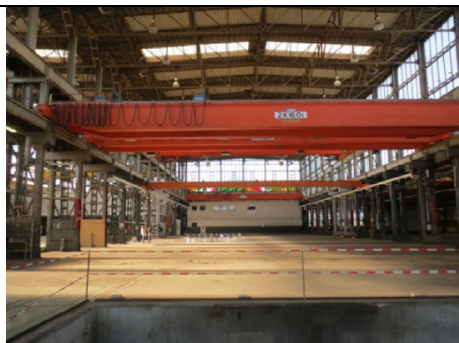

TEST B: Depicted you see an immense empty space. List as many different types of original ideas you can think of, and what you could do or change with ENERGY in this immense empty space. Think how you could use ENERGY in this immense empty space in uncommon ways. A common way might be: you could turn on the lights, you could move trains or walk in it. You are supposed to list as many different types of original ideas as possible for using ENERGY in this immense empty space. You have 5 minutes for this task.

\section{Cohort 1 (post-test) examples of original answers}

- Use a giant spiral to shoot things across the space

Create a water-wheel to create energy

- Make a biodiversity garden

- Use it as a space to shout out loud your frustrations

- Create positive energy

Create a space to think of original things like this assignment - Heat all metal parts of the space

- Build a science lab for studying the creation of energy

- Make a giraffe keep on walking on an assembly line

Cohort 1 (post-test) examples of non-original answers

Use it as a disco

Gererate heat

- Use it for lasergaming

- Make a nuclear station of it

Use it for a music performance

Build a sports facility in it

- Build a shopping mall in it

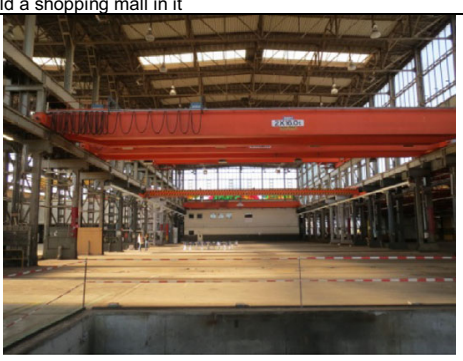

TEST A: Depicted you see an IMMENSE EMPTY SPACE. List as many different types of original ideas you can think of, and what you could do with or in this IMMENSE EMPTY SPACE. Think how you could use this IMMENSE EMPTY SPACE in uncommon ways. A common way might be: you could walk through it. You are supposed to list as many different types of original ideas as possible for using this IMMENSE EMPTY SPACE. You have 5 minutes for this task.

\section{Cohort 2 (post-test) examples of original answers}

- Repaint the entire space with nailpolish

Write down all your ideas on the floor

- Create echos by singing a piece by Bach

Make it a headquarters for a secret ninja gang

Create a giant fairground catching machine with the beams of this space

- Install a giant ventilator and fly a kite

- Use it for a mega-twister party

- Play the hero in your own story

- Use it for traveling through time

Cohort 2 (post-test) examples of non-original answers - Repaint it

- Use it for a party

Build an indoor swimming pool in it

- Build a rollerskate hall in it

Use it as a sports centre

- Use it for paintball fights

Fig. 2 Alternative uses tests and examples of original and non-original answers 
mental activities; (10) meeting; (11) learning; (12) living; (13) re-building (exterior); (14) (re)decorating (interior); (15) sporting; (16) transporting; (17) working. For each response, a category label was determined. For both tests (space and energy) we could use the same 17 categories. To determine the reliability of the flexibility scores, two raters each independently coded the same set of 737 responses. Inter-rater reliability was satisfactory ( $\kappa=0.76$, with a $95 \%$ interval between .73 and .79 for pre-test and post-test).

To determine originality, we opted for the concept of originality as statistical infrequency of original answers in the sample (Plucker et al. 2011). Originality was indicated by the sum of unique responses in the sample (for each cohort and each test). All responses were collected in a dataset. First, we deleted all non-interpretable responses (as explained, incomplete words, less than $1 \%$ of all answers from each test). Then we ordered all words alphabetically and calculated frequency scores for all responses. Subsequently, we combined all similar words while disregarding obvious spelling mistakes, typing errors and articles. Next, to determine the final frequency score, we combined all similar words that used grammatical variations or belonged to the same type of words. In this way, all responses were first separated into types (for example category: '(re)decorating the interior', type: 'painting'), tokens (for example 'painting the space white') and tones (for example 'repaint the entire space with nailpolish'), after which all answers received a final frequency score. For each student, the number of responses that did not occur in the rest of the sample was summed as the indicator of originality. Objective originality, therefore, is the sum of all unique responses for each student.

\section{Data analysis}

As the main analyses of this study contain analyses of variance, assumptions were first checked. Inspection of the QQ-plots of the three indicators of divergent thinking, for both pre-test and post-test of cohort 1 and cohort 2, seemed to indicate no violations of the assumption of a normal distribution. Furthermore, Levene tests on all indicators showed that the hypotheses of equal variances across conditions were not rejected (all $p>.05$ ).

The descriptive statistics of the three indicators are summarized in Table 5. In order to check the need for multivariate analyses, we calculated the correlation between the three indicators. For both cohorts, the indicators in the pre- and post-tests on divergent thinking were correlated: Cohort 1 fluency and flexibility $r=.73$ (pre) and $r=.70$ (post), fluency and originality $r=.56$ (pre) and $r=.80$ (post), and originality and flexibility $r=.34$ (pre) and $r=.54$ (post); Cohort 2 fluency and flexibility $r=.78$ (pre) and $r=.67$ (post); fluency and originality $r=.77$ (pre) and $r=.72$ (post), and originality and flexibility $r=.63$ (pre) and $r=.48$ (post). To check the stability between pre-tests and post-tests used, we calculated correlations between the same indicators of divergent thinking, which for Cohorts 1 and 2 respectively varied from $r=.52$ and $r=.53$ (fluency); $r=.38$ and $r=.40$ (flexibility); $r=.38$ and $r=.45$ (originality). To test whether students from the two conditions differed on the three indicators of divergent thinking in the pretest, we performed a multivariate analysis with condition as factor and fluency, flexibility and originality scores as dependent variables. In both Cohorts 1 and 2, the two conditions did not differ in the pre-test scores (Cohort 1 : Wilks' $\lambda(3,87)=.97 ; p=.37$, with fluency $(F(1,90)=0.78 ; p=.38)$, flexibility $(F(1,90)=2.13 ; p=.15)$ and originality $(F(1,90)=1.45 ; p=.23)$; Cohort 2 : Wilks' $\lambda(3,110)=.98 ; p=.49$, with fluency $(F(1,113)=2.44 ; p=.12)$, flexibility $(F(1$, $113)=1.16 ; p=.21)$ and originality $(F(1,113)=1.19 ; p=.28)$ ). 


\section{Results}

We performed multivariate analyses of covariance with condition as independent factor, fluency, flexibility and originality as dependent variables and the corresponding pretest scores as covariate, for both cohorts separately. For Cohort 1 , the analysis showed a significant effect of the intervention (Wilks' $\lambda(3,84)=.89 ; p=.02 ; \eta^{2}=.12$, observed power .78), with significant intervention effects for fluency $(F(1,90)=9.02 ; p=.003$; $\left.\eta^{2}=.10\right)$, flexibility $\left(F(1,90)=5.67 ; p=.02 ; \eta^{2}=.06\right)$ and originality $(F(1$, $\left.90)=9.95, p=.002 ; \eta^{2}=.10\right)$ all in favour of the experimental condition.

For Cohort 2, the analysis also showed a significant effect of the intervention (Wilks' $\lambda$ $(3,107)=.92 ; p=.02 ; \eta^{2}=.09$, observed power .74$)$, with significant intervention effects for fluency $\left(F(1,113)=7.14 ; p=.01 ; \eta^{2}=.06\right)$, flexibility $(F(1,113)=5.14$; $\left.p=.03 ; \eta^{2}=.05\right)$ and originality $\left(F(1,113)=8.12, p=.01 ; \eta^{2}=.07\right)$ all in favour of the experimental condition.

The two tests implemented in the study show lower mean scores for the pre-test on Energy for fluency and flexibility, compared to the Space test (see Table 5). Similarly, the fluency and flexibility scores on the post-test on Energy are relatively low, compared the Space test. However, this does not have consequences for the interpretation of the main results, which are about differences between intervention and comparison condition on the posttest scores, corrected for pre-test variances. Positive effects of a metacognitive strategy instruction of various creative generation activities were found on students' divergent thinking skill, indicated by fluency, flexibility and originality, both in Cohort 1 and in the replication in Cohort 2. These effects can be interpreted as medium (Cohort 1 fluency, $\eta^{2}=.10$; flexibility, $\eta^{2}=.06$; originality, $\eta^{2}=.10$, and Cohort 2 , fluency, $\eta^{2}=.06$; flexibility $\eta^{2}=.05$, and originality, $\eta^{2}=.07$ ) effect sizes (see Cohen 1988 , for rules of thumb of small, medium and large effect sizes).

Table 5 Results for fluency, flexibility and originality for Cohorts 1 and 2 for pre-test (left panel) and posttest (right panel)

\begin{tabular}{|c|c|c|c|c|c|c|c|c|c|c|c|c|}
\hline \multirow{3}{*}{$\begin{array}{l}\text { Indicators of divergent } \\
\text { thinking }\end{array}$} & \multicolumn{6}{|c|}{ Pre-test } & \multicolumn{6}{|c|}{ Post-test } \\
\hline & \multicolumn{3}{|c|}{$\begin{array}{l}\text { Cohort } 1 \\
\text { (Space test) }\end{array}$} & \multicolumn{3}{|c|}{$\begin{array}{l}\text { Cohort } 2 \\
\text { (Energy test) }\end{array}$} & \multicolumn{3}{|c|}{$\begin{array}{l}\text { Cohort } 1 \\
\text { (Energy test) }\end{array}$} & \multicolumn{3}{|c|}{$\begin{array}{l}\text { Cohort } 2 \\
\text { (Space test) }\end{array}$} \\
\hline & $N$ & $M$ & $S D$ & $N$ & $M$ & $S D$ & $N$ & $M$ & $S D$ & $N$ & $M$ & $S D$ \\
\hline \multicolumn{13}{|l|}{ Fluency } \\
\hline Intervention & 50 & 16.32 & 6.07 & 64 & 12.06 & 6.51 & 50 & 17.26 & 7.21 & 64 & 19.53 & 8.60 \\
\hline Comparison & 41 & 17.59 & 7.58 & 50 & 14.04 & 6.95 & 41 & 14.41 & 6.12 & 50 & 17.32 & 8.30 \\
\hline \multicolumn{13}{|l|}{ Flexibility } \\
\hline Intervention & 50 & 7.52 & 2.24 & 64 & 5.61 & 2.33 & 50 & 7.16 & 2.46 & 64 & 8.27 & 2.37 \\
\hline Comparison & 41 & 8.22 & 2.32 & 50 & 6.18 & 2.44 & 41 & 6.41 & 1.96 & 50 & 7.54 & 2.79 \\
\hline \multicolumn{13}{|l|}{ Originality } \\
\hline Intervention & 50 & 5.34 & 3.99 & 64 & 5.38 & 3.99 & 50 & 9.26 & 5.68 & 64 & 9.44 & 5.81 \\
\hline Comparison & 41 & 6.39 & 4.32 & 50 & 6.20 & 4.03 & 41 & 7.02 & 3.29 & 50 & 7.68 & 4.25 \\
\hline
\end{tabular}




\section{Discussion and conclusions}

Albeit statistically medium effects, we think we have found important effects on the three indicators of divergent thinking, taken into account the short span of the intervention of the experimental condition of just $50 \mathrm{~min}$ and the complexity of the process of enhancing original ideas. The intervention focused on students' metacognitive knowledge and metacognitive skills in creative processes and the divergent thinking activities and strategies used in these processes. Due to the molar characteristic of the intervention-an explicit metacognitive strategy instruction on divergent thinking - it is impossible to single out one specific element as the element that might have caused the effect.

In the experimental condition, students were stimulated through explicit instruction to focus on a better representation of their mental model on creativity and divergent thinking-i.e., the meta-level - and were explicitly stimulated through activities to focus on monitoring and control of their divergent thinking surpassing students' idiosyncratic perceptions of creativity that could hamper students' divergent thinking. Divergent thinking activities and the generation of original ideas were explained, discussed and modeled, by using and illustrating the two dimensions of the matrix (Table 1). In this intervention lesson, students also learned about metacognitive skills for regulation, related to their own metacognitive monitoring and control processes of the specific and rather complex divergent thinking activities and strategies. Students from the experimental condition were stimulated to deliberately use divergent thinking strategies in real world exercises (Table 3, lesson phase 8) and to monitor and control their generation processes (Table 3, lesson phase 8 and 9).

Students from the comparison condition were stimulated to apply brainstorming activities related to their own visual art products (Table 4, lesson phase 5) without teachers explaining metacognitive knowledge about divergent thinking and without explicit stimulation to monitor their generation processes. In the intervention lesson of the comparison condition, students were brainstorming and reflecting on the content of the theme of 'Timegrasping' and they were able to learn by exercising, evaluation and feedback, to focus on activities at object-level: creating ideas for their individual photography series.

In sum, in the redesigned intervention lesson of the experimental condition, three aspects were added: (1) knowledge about twelve specific activities in divergent thinking (2) knowledge about strategies of divergent thinking aimed at generation through remoteness and through abstractness (3) an instructional design focusing on enhancement of students' metacognitive knowledge and skills to regulate-monitor and control-these complex divergent thinking processes aimed at generating original ideas.

\section{Limitations}

In our study we focused on enhancement of divergent thinking through explicit metacognitive strategy instruction. We now know that the combination of the components of the intervention is more effective than a regular brainstorm lesson for divergent thinking, in two experiments, but we do not know to what extent each separate component contributed to the effects found. Although we found positive effects of the instruction lesson for the experimental condition as compared to the comparison condition, and we can construct the relation between divergent thinking and metacognitive regulation processes that are required to enhance performance, we do not have data to determine to what extent precisely students' metacognitive divergent thinking processes differed in both conditions. 
We assume that the key-element is raising students' awareness about their divergent thinking skills, and-as we assumed when we designed the intervention-that the combination of the components of the intervention would contribute to this awareness. Further research will be needed to analyze whether and to what extent metacognitive knowledge and metacognitive regulation are (both) needed to achieve these effects.

A possible limitation is that classes were randomly assigned to the experimental and comparison condition. This design implies that a potential bias from the specific characteristics of each condition cannot entirely be excluded, although all students were from the same school level, from Grade-11 groups, belonged to the same age, and conditions did not differ on divergent thinking skills in the pre-test.

Our intervention included Grade-11 students aged 16-17 and recruited from one school in the Netherlands. This means that results are in principle limited to generalize these to wider populations. Nevertheless, we found positive effects in both Cohort 1 and Cohort 2, which supports generalizability to a certain degree. We therefore assume that the results can be generalized to other secondary school students and possibly to other grades and ages of students in secondary education, provided these students are able to understand the rather complex nature of the instruction.

Another issue that might be seen as limitation of the study is the sample-specific character of the measurement of originality in divergent thinking. We followed Plucker et al. (2004), who related originality to a social context and considered it therefore as a social construct. By using the objective scoring method-a method that performed well in terms of convergent and predictive validity according to the study by Plucker et al. (2011) — answers given only once in this particular sample are considered as unique and original.

\section{Future studies}

Future studies should focus on the extent to which the effects of this type of intervention were either of a general or of a domain-specific nature-i.e., specific for the domain of visual arts. To generate many different types of original ideas, students not only need the vocabulary to list their ideas, but they also need skills in envisioning, as we explained in our theoretical framework. However students also need skills to visualize their ideas in art production. In this study, we found positive effects of the instruction on students' divergent thinking skills, measured with an alternative uses test, an instrument which is often used for measuring divergent thinking. The question then is whether students possessing both knowledge and skills in divergent thinking as a strategy actually do apply these skills in their creative visual processes without any extra exercises or skills, this should be studied in further research. The specific relations between divergent thinking, original ideas, original concepts for artworks and the production of original artworks in visual arts education also needs to be examined further. To be able to further examine the relation between divergent thinking and the originality of final artworks in a more detailed way, reliable, valid and feasible assessment procedures and instruments for visual arts education should be developed first. Future studies could also focus then, on expanding or combining the interventions we have examined in this study.

We showed that a 50 min metacognitive strategy instruction had a positive effect on students' fluency, flexibility and originality. The complex nature of sub-processes and the number of different activities involved in divergent thinking requires more than applying brainstorming activities to result in such effects. Therefore, we think that including an 
explicit metacognitive strategy instruction when students prepare their art productions via brainstorming lessons can be an effective.

Open Access This article is distributed under the terms of the Creative Commons Attribution 4.0 International License (http://creativecommons.org/licenses/by/4.0/), which permits unrestricted use, distribution, and reproduction in any medium, provided you give appropriate credit to the original author(s) and the source, provide a link to the Creative Commons license, and indicate if changes were made.

\section{References}

Acar, S., \& Runco, M. A. (2014). Assessing associative distance among ideas elicited by tests of divergent thinking. Creativity Research Journal, 26(2), 229-238. doi:10.1080/10400419.2014.901095.

Askell-Williams, H., Lawson, M. J., \& Skrzypiec, G. (2012). Scaffolding cognitive and metacognitive strategy instruction in regular class lessons. Instructional Science, 40(2), 413-443. doi:10.1007/ s11251-011-9182-5.

Barak, M. (2013). Impacts of learning inventive problem-solving principles: Students' transition from systematic searching to heuristic problem solving. Instructional Science, 41(4), 657-679. doi:10.1007/ s11251-012-9250-5.

Benedek, M., Könen, T., \& Neubauer, A. (2012). Associative abilities underlying creativity. Psychology of Aesthetics, Creativity, and the Arts, 6(3), 273-281. doi:10.1037/a0027059.

Boden, M. A. (2004). The creative mind. Myths and mechanisms (2nd ed.). London: Routledge.

Bresson, R. (2004). Responding to art: Form, content, and context. New York: McGraw-Hill.

Cohen, J. (1988). Statistical power analysis for the behavioural sciences (2nd ed.). Hillsdale: Lawrence Erlbaum Associates.

Cohen, B., \& Murphy, G. L. (1984). Models of concepts. Cognitive Science, 8(1), 27-58. doi:10.1207/ s15516709 $\operatorname{cog} 0801 \_2$.

Collins, A. M., \& Loftus, E. F. (1975). A spreading-activation theory of semantic processing. Psychological Review, 82(6), 407. doi:10.1037/0033-295X.82.6.407.

Davidson, J. E., \& Sternberg, R. J. (Eds.). (2003). The psychology of problem solving. Cambridge: Cambridge University Press.

Dignath, C., \& Büttner, G. (2008). Components of fostering self-regulated learning among students. A metaanalysis on intervention studies at primary and secondary school level. Metacognition and Learning, 3(3), 231-264. doi:10.1007/s11409-008-9029-x.

Eberle, B. (2008). Scamper: Creative games and activities for imagination development. Waco: Prufrock Press.

Elshout-Mohr, M., Van Hout-Wolters, B. H. A. M., \& Broekkamp, H. (1999). Mapping situations in classroom and research: Eight types of instructional-learning episodes. Learning and Instruction, 9(1), 57-75. doi:10.1016/S0959-4752(98)00020-6.

Finke, R. A. (1990). Creative imagery: Discoveries and inventions in visualization. Hillsdale, NJ: Erlbaum.

Flavell, J. H. (1979). Metacognition and cognitive monitoring: A new area of cognitive-developmental inquiry. American Psychologist, 34(10), 906. doi:10.1037/0003-066X.34.10.906.

Gentner, D., \& Markman, A. B. (1997). Structure mapping in analogy and similarity. American Psychologist, 52(1), 45-56. doi:10.1037/0003-066X.52.1.45.

Gibbert, M., Hampton, J. A., Estes, Z., \& Mazursky, D. (2012). The curious case of the refrigerator-TV: Similarity and hybridization. Cognitive Science, 36(6), 992-1018. doi:10.1111/j.1551-6709.2012. 01247.x.

Gilhooly, K. J., Fioratu, E., Anthony, S. H., \& Wynn, V. (2007). Divergent thinking: Strategies and executive involvement in generating novel uses for familiar objects. British Journal of Psychology, 98(4), 611-625. doi:10.1348/096317907X173421.

Groenendijk, T., Jansen, T., Rijlaarsdam, G., \& van den Bergh, H. (2013). The effect of observational learning on students' performance, processes, and motivation in two creative domains. British Journal of Educational Psychology, 83(1), 3-28. doi:10.1111/j.2044-8279.2011.02052.x.

Hampton, J. A. (1987). Inheritance of attributes in natural concept conjunctions. Memory \& Cognition, 15(1), 55-71. doi:10.3758/BF03197712.

Hampton, J. A. (1996). Conceptual combination. In K. Lamberts \& D. Shanks (Eds.), Knowledge, concepts and categories (pp. 135-162). London: UCL Press. 
Hetland, L., Winner, E., Veenema, S., \& Sheridan, K. M. (2007). Studio thinking. The real benefits of visual arts education. New York: Teachers College Press.

Holyoak, K. J., \& Thagard, P. (1989). Analogical mapping by constraint satisfaction. Cognitive Science, 13(3), 295-355. doi:10.1207/s15516709 $\operatorname{cog} 1303 \_1$.

Houtveen, A. A. M., \& van de Grift, W. J. C. M. (2007). Effects of metacognitive strategy instruction and instruction time on reading comprehension. School Effectiveness and School Improvement, 18(2), 173-190. doi:10.1080/09243450601058717.

Hunter, S. T., Bedell-Avers, K. E., Hunsicker, C. M., Mumford, M. D., \& Ligon, G. S. (2008). Applying multiple knowledge structures in creative thought: Effects on idea generation and problem-solving. Creativity Research Journal, 20(2), 137-154. doi:10.1080/10400410802088779.

Jaarsveld, S., \& van Leeuwen, C. (2005). Sketches from a design process: Creative cognition inferred from intermediate products. Cognitive Science, 29(1), 79-101. doi:10.1207/s15516709cog2901_4.

Kiefer, M., Marzinzik, F., Weisbrod, M., Scherg, M., \& Spitzer, M. (1998). The time course of brain activations during response inhibition: Evidence from event-related potentials in a go/no go task. Neuroreport, 9(4), 765-770.

Kokinov, B., Petkov, G., \& Petrova, N. (2007). Context-sensitivity of human memory: Episode connectivity and its influence on memory reconstruction. In B. Kokinov, D. Richardson, Th Roth-Berghofer, \& L. Vieu (Eds.), CONTEXT 2007 (pp. 317-329). Berlin: Springer.

Ku, K. Y. L., \& Ho, I. T. (2010). Metacognitive strategies that enhance critical thinking. Metacognition and Learning, 5(3), 251-267. doi:10.1007/s11409-010-9060-6.

Leder, H., Belke, B., Oeberst, A., \& Augustin, D. (2004). A model of aesthetic appreciation and aesthetic judgments. British Journal of Psychology, 95(4), 489-508. doi:10.1348/0007126042369811.

Mednick, S. A. (1962). The associative basis of the creative process. Psychological Review, 69(3), $220-232$. doi:10.1037/h0048850.

Merrill, M. D. (2001). Components of instruction toward a theoretical tool for instructional design. Instructional Science, 29(4-5), 291-310. doi:10.1023/A:1011943808888.

Merrill, M. D. (2002). First principles of instruction. Educational Technology Research and Development, 50(3), 43-59. doi:10.1007/BF02505024.

Michalko, M. (1991). Thinkertoys. Berkeley: Ten Speed Press.

Nelson, T. O., \& Narens, L. (1990). Metamemory: A theoretical framework and new findings. In G. H. Bower (Ed.), The psychology of learning and motivation. Advances in research and theory (Vol. 26, pp. 125-173). San Diego, California: Academic Press.

Nijstad, B. A., De Dreu, C. K. W., Rietzschel, E. F., \& Baas, M. (2010). The dual pathway to creativity model: Creative ideation as a function of flexibility and persistence. European Review of Social Psychology, 21(1), 34-77. doi:10.1080/10463281003765323.

Perkins, D. N. (1994). Creativity: Beyond the darwinian paradigm. In M. A. Boden (Ed.), Dimensions of creativity (pp. 119-142). Cambridge: MIT Press/Bradford Books.

Peterson, J. B., Smith, K. W., \& Carson, S. (2002). Openness and extraversion are associated with reduced latent inhibition: Replication and commentary. Personality and Individual Differences, 33(7), 1137-1147. doi:10.1016/S0191-8869(02)00004-1.

Plucker, J., Beghetto, R. A., \& Dow, G. (2004). Why isn't creativity more important to educational psychologists? Potential, pitfalls, and future directions in creativity research. Educational Psychologist, 39(2), 83-96. doi:10.1207/s15326985ep3902_1.

Plucker, J. A., Qian, M., \& Wang, S. (2011). Is originality in the eye of the beholder? Comparison of scoring techniques in the assessment of divergent thinking. Journal of Creative Behavior, 45(1), 1-22. doi:10. 1002/j.2162-6057.2011.tb01081.x.

Ranellucci, J., Muis, K. R., Duffy, M., Wang, X., Sampasivam, L., \& Franco, G. M. (2013). To master or perform? Exploring relations between achievement goals and conceptual change learning. British Journal of Educational Psychology, 83(3), 431-451. doi:10.1111/j.2044-8279.2012.02072.x.

Ross, V. E. (2006). A model of inventive ideation. Thinking Skills \& Creativity, 1(2), 120-129. doi:10.1016/ j.tsc.2006.06.003.

Runco, M. A. (2010). Divergent thinking, creativity and ideation. In J. C. Kaufman \& R. J. Sternberg (Eds.), The Cambridge handbook of creativity (pp. 413-446). New York: Cambridge University Press.

Runco, M. A., \& Okuda, S. M. (1991). The instructional enhancement of the flexibility and originality scores of divergent thinking tests. Applied Cognitive Psychology, 5(5), 435-441. doi:10.1002/acp. 2350050505.

Sawyer, R. K. (2012). Explaining creativity, Ch. 2 (2nd ed., pp. 116-118). New York: Oxford University Press. 
Schlegel, A., Alexander, P., Fogelson, S. V., Li, X., Lu, Z., Kohler, P. J., et al. (2015). The artist emerges: Visual art learning alters neural structure and function. NeuroImage, 105, 440-451. doi:10.1016/j. neuroimage.2014.11.014.

Schraw, G. (1998). Promoting general metacognitive awareness. Instructional Science, 26(1-2), 113-125. doi:10.1023/A:1003044231033.

Schraw, G., \& Gutierrez, A. P. (2015). Metacognitive strategy instruction that highlights the role of monitoring and control processes. In S. Peňa-Ayala (Ed.), Metacognition: Fundaments, applications, and trends (pp. 3-16). Cham: Springer.

Scott, G., Leritz, L. E., \& Mumford, M. D. (2004). The effectiveness of creativity training: A quantitative review. Creativity Research Journal, 16(4), 361-388. doi:10.1080/10400410409534549.

Seidel, S., Tishman, S., Winner, E., Hetland, L., \& Palmer, P. (2009). The qualities of quality. Understanding excellence in arts education. Cambridge: Harvard Project Zero.

Serra, M. J., \& Metcalfe, J. (2009). Effective implementation of metacognition. In D. J. Hacker, J. Dunlosky, \& A. C. Graesser (Eds.), Handbook of metacognition in education (pp. 278-298). London: Routledge.

Smith, E. E., \& Osherson, D. N. (1984). Conceptual combination with prototype concepts. Cognitive Science, 8(4), 337-361. doi:10.1207/s15516709cog0804_2.

Soderberg, C. K., Callahan, S. P., Kochersberger, A. O., Amit, E., \& Ledgerwood, A. (2014). The effects of psychological distance on abstraction: Two meta-analyses. Psychological Bulletin, 141(3), 525-548. doi:10.1037/bul0000005.

Stocker, K. (2012). The time machine in our mind. Cognitive Science, 36(3), 385-420. doi:10.1111/j.15516709.2011.01225.x.

van de Kamp, M. T., Admiraal, W., Van Drie, J., \& Rijlaarsdam, G. (2015). Enhancing divergent thinking in visual arts education: Effects of explicit instruction of meta-cognition. British Journal of Educational Psychology, 85(1), 47-58. doi:10.1111/bjep.12061.

Ward, T. B., Patterson, M. J., \& Sifonis, C. M. (2004). The role of specificity and abstraction in creative idea generation. Creativity Research Journal, 16(1), 1-9. doi:10.1207/s15326934crj1601_1.

Welling, H. (2007). Four mental operations in creative cognition: The importance of abstraction. Creativity Research Journal, 19(2-3), 163-177. doi:10.1080/10400410701397214.

Zahner, D., Nickerson, J. V., Tversky, B., Corter, J. E., \& Ma, J. (2010). A fix for fixation? Rerepresenting and abstracting as creative processes in the design of information systems. Artificial Intelligence for Engineering Design, Analysis and Manufacturing, 24(2), 231-244. doi:10.1017/S0890060410000077. 